\title{
Spatial Distribution of Heavy Metals in Al-Zarqa, Jordan
}

\section{Reem Dabaibeh}

Department Physics and Applied Sciences, Faculty of Engineering Technology, Al-Balqa' Applied University, Al-Salt, Jordan

\section{* Corresponding author:}

tel: $+962-798903008$

email: reem.dabaibeh@bau.edu.jo

Received: July 31, 2020

Accepted: September 21, 2020

DOI: $10.22146 / \mathrm{ijc} .58304$

\begin{abstract}
Al-Zarqa is experiencing challenges in industry conversion and extensive urbanization. The environmental quality of soil in the Al-Zarqa region was analyzed by Spatial analysis for the identification of sources and estimation of the concentration of heavy metals, which helped in the assessment of soil quality and heavy metal pollution. The reason for the elevation of heavy metal pollution is increased urbanization, industrialization, traffic, oil refinery emissions, and mixed anthropogenic sources in that region. The main objective of this research was to assess the ecological impact of heavy metal pollutants in the Al-Zarqa region. The concentrations of $\mathrm{Cd}, \mathrm{Cr}, \mathrm{Cu}, \mathrm{Mn}, \mathrm{Ni}, \mathrm{Pb}, \mathrm{Zn}$, and Fe were estimated and compared with the existing literature. The distribution pattern of each metal was identified by spatial distribution analysis. Results revealed that the concentration of $\mathrm{Cd}, \mathrm{Cr}$, and $\mathrm{Ni}$ ) was high, while the concentration of $\mathrm{Pb}, \mathrm{Zn}$, and $\mathrm{Cu}$ was lower than the maximum allowed limits. Factor analysis identified the potential sources of heavy metals in the investigated area, and spatial distribution showed the geographical distribution of the heavy metals over the study area. It was concluded that identification of the potential sources of pollutants along with their geographical variations was more beneficial than only considering the individual point concentrations.
\end{abstract}

Keywords: heavy metals; soil pollution; Al-Zarqa; genotoxicity

\section{- INTRODUCTION}

Heavy metal pollution is one of the biggest challenges of the present century. Heavy metals cause negative impacts on aquatic and terrestrial organisms. These pollutants are also affecting the economy of the farming community [1]. Since the shortage of freshwater is a great concern in Jordan [2], the heavy metals available in drinking water can be considered as a threat to human health. The oncogenic risk of such metals has been proven in several studies [3]. The environmental occurrence of heavy metals is also causing adversarial effects on human health [4]. Heavy metal poisoning is identified as an important underlying factor for several diseases. These metallic elements have a relatively higher density than water [5].

Metal pollutants are one of the major environmental concerns across the globe [6]. Their presence could pose risks and hazards to humans and their trace levels in the environment are regulated by various laws and various authorities in each country [7]. Industrial, agricultural, and domestic development have also increased human exposure to heavy metals. Although these metals are naturally occurring elements in soil, major sources of metals in the environment include anthropogenic activities, industrial waste, agricultural practices, pharmaceuticals, and metal based industry operations [8]. Environmental pollution by heavy metals is considered dangerous and is particularly hazardous to human health [9]. Mineral rock weathering is also a well-identified source of metal pollutants in the environment [10].

Many studies have identified that the concentration of hazardous metals in topsoil is persistently increasing. Yaseen and Al-Hawari [11] discussed that there is a momentous increase in the total contents of metals in soils in areas experiencing increased industrialization. The major soil contaminants include $\mathrm{Pb}, \mathrm{Cd}, \mathrm{Zn}$, and $\mathrm{Cu}$, which are released into the environment through mechanical abrasion [12]. Soil contamination with metal ions is also increased through metal corrosion, soil erosion, and 
other natural phenomena. Industrial sources such as oil refineries, petroleum combustion, power-plants, and recycling and waste treatment plants are also important contributors of these metals in the environment [2]. Metals such as cobalt (Co), copper $(\mathrm{Cu})$, chromium (Cr), iron $(\mathrm{Fe})$, manganese $(\mathrm{Mn})$, molybdenum (Mo), nickel $(\mathrm{Ni})$, selenium (Se), and zinc ( $\mathrm{Zn})$ are considered as vital nutrients for biochemical activities. Therefore, agricultural practices are also contributing to soil contamination of metals [4].

Heavy metal ions are toxic as they can gather in the human body and affect the central nervous system. Heavy metal poisoning is a serious health issue that causes physiological and neurological health problems [13]. The most hazardous metals to human health include $\mathrm{Hg}, \mathrm{Pb}$, $\mathrm{Cd}, \mathrm{Au}, \mathrm{Pt}, \mathrm{Ag}, \mathrm{Bi}, \mathrm{As}, \mathrm{Se}, \mathrm{V}, \mathrm{Cr}$, and Ti [12]. Metal ions can interact with cell components such as DNA and cause carcinogenesis. Metals are also causing oxidative stress in the human body, which results in the carcinogenicity of these metals [11]. The level of exposure to heavy metals decides the degree of toxicity and their carcinogenic effects. High exposure to these metals may result in multiple organ failure and life-threatening situations [13].

Al-Zarqa has been experiencing rapid and uncontrolled urbanization and industrialization, resulting in the increase of environmental problems in this region. Heavy metals, which pose a potential health risk for human beings, are ubiquitous pollutants in urban dust because of the increase in urban population and intensity of anthropogenic activities [14].

Jordan Petroleum Refinery Company (JPRC), situated in Al-Zarqa, is a primary source of pollution and other environmental problems [15]. Al-Hussein thermal power stations, Russeifa dump, and Es-ssammra wastewater treatment complex are also important sources of pollutants in the environment [16]. The purpose of this study is to assess the key sources of pollutants in Al-Zarqa and compare the metal contamination in this region. The heavy metal contents in the soil were identified, and their concentration was measured.

Naser [10] studied the sources of contamination in soil and found that the metals naturally occur in the soil as a result of rock weathering. Metals occur in trace quantities in the environment and are often not toxic. Gao and Chen [5] highlighted that urbanization in various areas could disturb and accelerate the natural geochemical cycle of metals and results in their amassing in soil. According to Li et al. [1], anthropogenic sources are also important contributors to metal pollutants in soil. To assess the level of anthropogenic contamination of soil, it is necessary to conduct special monitoring studies. The issue of anthropogenic soil pollution caused by emissions from coal-fired thermal power stations has been studied worldwide, especially in countries where coal mining is an important industry [17]. They further added that metal mine tailings, petrochemicals, fertilizers, pesticides, landfilling with metal compounds, lead-based paints are also important sources of metal deposition in soil.

El-Hasan and Lataifeh [2] studied the impact of essential micronutrients in soil. Their findings revealed that micronutrients, including $\mathrm{Co}, \mathrm{Cu}, \mathrm{Fe}, \mathrm{Mn}, \mathrm{Mo}, \mathrm{Ni}$, and $\mathrm{Zn}$, are crucial for plants and are frequently used in fertilizers. Several metals, which are essential as nutrients in lower concentrations (i.e. $\mathrm{Zn}, \mathrm{Cu}, \mathrm{Fe}$, and $\mathrm{Mn}$ ) can be considered harmful for plant growth if the levels of these elements in soil and atmosphere are increased [18]. The fertilizers used to supply these nutrients to soil frequently contain trace amounts of metals, including $\mathrm{Cd}$ and $\mathrm{Pb}$. Some phosphate base fertilizers also contain impurities of $\mathrm{F}$ and $\mathrm{Hg}$. The excessive use of these fertilizers also contributes to the accumulation of metals in soil. Yaseen and Al-Hawari [11] also presented similar findings and revealed that more than $10 \%$ of the pesticides and fungicides commonly used in agriculture are based on compounds that contain $\mathrm{Cu}, \mathrm{Hg}, \mathrm{Mn}, \mathrm{Pb}$, or $\mathrm{Zn}$. These compounds are also an important source of soil contamination.

Municipal and industrial wastewater is an extensively discussed source of soil contamination. Wang et al. [6] found that industrial waste and effluents are commonly discharged over land. Their findings revealed that more than 20 million hectares of land received wastewater annually around the globe. Meanwhile, Al-Khashman [12] found that in developing countries, around $50 \%$ of the irrigation is based on 
wastewater supply. The negative impact of heavy metal accumulation in soils includes the decrease of the yield and quality of crops, and also the quality of the atmospheric and aquatic environments. Generally, irrigation with wastewater elevates the total and available heavy metal concentrations in soils [19]. Even if the wastewater contains relatively low amounts of heavy metals, enduring exposure to this kind of wastewater can result in significant amassing of metal pollutants in soil.

Al-Taani et al. [20] studied the impact of urbanization on the heavy metals contamination in soil. The study identified that urbanization affected the ecological functions and increased $\mathrm{Zn}$ accumulation in soil. According to Massadeh et al. [21], sewage sludge, livestock manures, vehicle exhaust, industrial emission, and agricultural practices have become major environmental concerns worldwide. The extent of urbanization and increased population can significantly affect the inherent function of soil and facilitate the accumulation of polluted contents, as discussed by Zhang et al. [4].

According to Al-Najjar et al. [15], the natural concentration of trace elements in soil plays a critical role in controlling the effect of human activities on the soil. Heavy metals in urban soils have been widely studied due to their ubiquity, toxicity, and persistence [22]. The amassing of metals in topsoil is contributed through several environmental and human activities. Massadeh et al. [21] studied the urban population index map of different regions, and their findings revealed that in urban areas, the soil is found to be enriched in heavy metals. Soil pollution by heavy metals in industrialized areas is an ongoing challenge.

Spatial analysis is frequently used to quantify the quality of soil and to assess the presence of contamination in soil. According to Al-Taani et al. [20], spatial analysis is an important predictive approach to assess the impact of urbanization on soil quality and the presence of heavy metals. The accuracy of heavy metal spatial distribution maps is critical for risk control [23]. The spatial distribution of metal ions helps in the assessment of the concentration of these pollutants in soil. According to Shan et al. [8], the rising values of these metals indicate toxicity and soil pollution. Alloway [24] suggests that heavy metals are toxic and not easy to decompose naturally. These metals are transferred from soil to the environment through water, plants, and contaminated foods.

Coal mining industries generate large volumes of gangue wastes, from which a considerable amount of toxic HMs could be released during weathering of the waste under the joint effects of water, microorganisms, vegetation, sunlight radiation, and heat. These hazardous substances enter the ecosystem by a variety of pathways where they could be detrimental to crops and animals, and might be taken up by humans through direct contact (ingestion, dermal absorption, and inhalation) or food chains [25].

Abderahman and Abu-Rukah [16] showed that heavy metal toxicity in the soil gradually increased through anthropogenic processes, including waste dumping in landfills, waste incineration, and smokestack emission. They also stated that the US environmental protection agency had identified seven metals as the priority control pollutants known for their hazardous effects on human health. These metals include nickel, zinc, copper, lead, mercury, arsenic, cadmium, and chromium. Al-Khashman [12] identified that contamination of these metal pollutants in the soil is a serious and rapidly growing problem in regions that are experiencing industrial development and urban expansion.

According to Li et al. [13], the level of topsoil contamination can be assessed through their spatial distribution. They defined spatial analysis as a geographical process that involves the topological, geometrical, and geographical properties of soil. It is based on the analysis of the pattern of human behaviors and their spatial expression. Al-Khashman [26] highlighted that spatial analysis is used to identify location-oriented problems. Digital mapping and spatial analysis are commonly used to characterize the soil quality and assess the spatial distribution of metals. Jaradat et al. [27] performed the comparison of nonrestructured soil and restructured soil through the spatial distribution of heavy metals. The spatial variability of soil properties includes variations in soil moisture, physical and chemical properties, etc. 
Moreover, temporal and spatial variations of heavy metals relate to both natural variability of soils and human activities, thus to be considered as powerful tracers for monitoring the impact of human activity [28]. Their findings revealed that territorial and human factors subsidize the gathering of various pollutants in soil, including heavy metals.

Al-Khashman [26] studied the extent of contamination in topsoil and spatial distribution of metals. Their findings indicated that the concentrations of $\mathrm{Pb}, \mathrm{Cu}, \mathrm{Cr}, \mathrm{Zn}$, and $\mathrm{Cd}$ are higher in areas near industries. They identified that the accretion of these metals was higher in areas near cement factories. Al-Khashman [12] studied the heavy-metals concentration in the urban samples of topsoil from Jordan. According to their findings, $\mathrm{Zn}$ and $\mathrm{Pb}$ had high concentrations, while $\mathrm{Cd}$ and $\mathrm{Ni}$ had lower concentrations. It was further concluded that large scale industrialization is a major factor for soil degradation and heavy metal pollution.

Al-Khashman [26] studied the extent of pollution in Karak Industrial estate, Jordan. Their findings revealed that the soil in the studied area was polluted with metals, including $\mathrm{Fe}, \mathrm{Cu}, \mathrm{Zn}$, and $\mathrm{Pb}$. They also found that the concentration of these metals exceeded the limits in topsoil, but their concentration was found to be decreased in lower soil. They concluded that the main sources of these pollutants were the nearby industrial places. El-Hasan and Lataifeh [2] extended the discussion by analyzing the topsoil composition in the Nepal region. They analyzed the amounts of eight trace metals, including $\mathrm{Cd}, \mathrm{Cr}, \mathrm{Cu}$, $\mathrm{Fe}, \mathrm{Mn}, \mathrm{Pb}, \mathrm{V}$, and $\mathrm{Zn}$. Their findings suggested that $\mathrm{Pb}$ and $\mathrm{Zn}$ were greater in concentration near the metropolitan regions while $\mathrm{Cr}, \mathrm{Fe}$, and $\mathrm{V}$ were found in exceeding concentrations in controlled soil.

Banat et al. [29] performed the spatial pattern study of metal pollutants in central Jordan. They identified that $\mathrm{Cd}, \mathrm{Pb}$, and $\mathrm{Hg}$ were found to be in high concentrations in urban areas. They also identified the major sources of these pollutants to be the cement industry, fertilizers, and vehicle emission. These metals were found in both residual and active phases. Al-Khashman and Shawabkeh [30] studied the distribution analysis of $\mathrm{Pb}, \mathrm{Zn}, \mathrm{Cd}$, and $\mathrm{Cr}$ in Southern Jordan near industrial areas. Their results highlighted that $\mathrm{Pb}, \mathrm{Zn}$, and $\mathrm{Cd}$ were in higher concentration in areas near the cement manufacturing plant. The study further stated that anthropogenic activities are the major contributors to the pollutants in urban soil.

Soil, an important environmental medium, is exposed to a number of pollutants including toxic heavy metals by various natural and anthropogenic activities [19]. Extensive urbanization and industrialization lead to the accretion of toxic metals in topsoil. The current study is aimed to assess the sources of contamination and amounts of heavy metals in the Al-Zarqa region of Jordan.

\section{- EXPERIMENTAL SECTION}

\section{Materials}

Analytical reagent-grade of acids, bases, nitrate salts of metals, and other chemicals obtained from Merck (Darmstadt, Germany) were used as received. All solutions were prepared in double deionized water (DDW). All plastics and glassware were cleaned by soaking in $\mathrm{HNO}_{3}$ solution $(10 \% \mathrm{v} / \mathrm{v})$ and then rinsed with DDW before use. The stock standard solutions of analytes (1000 $\mathrm{mg} \mathrm{L}^{-1}$ ) were prepared from analytical grade nitrate salts of the analytes. The working standard solutions were prepared by appropriate dilution of the stock solutions. ATP was purchased from Sigma-Aldrich [31].

\section{Instrumentation}

A Shimadzu model AA-680 atomic absorption spectrometer (Japan) with a hollow cathode lamp as a radiation source and a deuterium background corrector at respective wavelengths (using an air-acetylene flame) was used for metal ions determination in standard and sample solutions. All operating parameters were those recommended by the manufacturer. A Metrohm 691 $\mathrm{pH} /$ ion meter (Buchs, Switzerland) supplied with a combined glass-calomel electrode was used for the $\mathrm{pH}$ adjustments. The size and morphology of GO were observed by TEM using a CM120 microscope (Philips, Netherlands). Raman spectra of GO were prepared using a SENTERRA microscope (BRUKER, Germany). FT-IR spectra were taken on a BRUKER VECTOR 22 Spectrometer. The flow of the sample and eluent 
through the column was adjusted using a 10 roller peristaltic pump (Ultrateck Labs Co. Iran) [31].

\section{Procedure}

\section{Studied area}

$\mathrm{Al}$-Zarqa is situated in the northeast part of Jordan, at the basin of the Zarqa River, Fig. 1. It has a total area of $4586 \mathrm{~km}^{2}$; about $4074 \mathrm{~km}^{2}$ of which is within Jordan and $512 \mathrm{~km}^{2}$ is within Syria [32].The city is located northeast of Amman and has a population of more than 640,000 inhabitants. The city is experiencing extensive industrialization and urbanization since the past decades. The Al Zarqa Channelized Stream is considered to be one of the most polluted regions in Jordan due to massive discharge and accumulation of pollutants over the years [33]. The city is situated near the international AmmanBaghdad highway. It is also the main industrial center of Jordan, and more than $50 \%$ of the country's industries are situated in this city. Jordan oil refinery plants, leather and garment factories, new agricultural and pharmaceutical factories represent the recent industrial development in

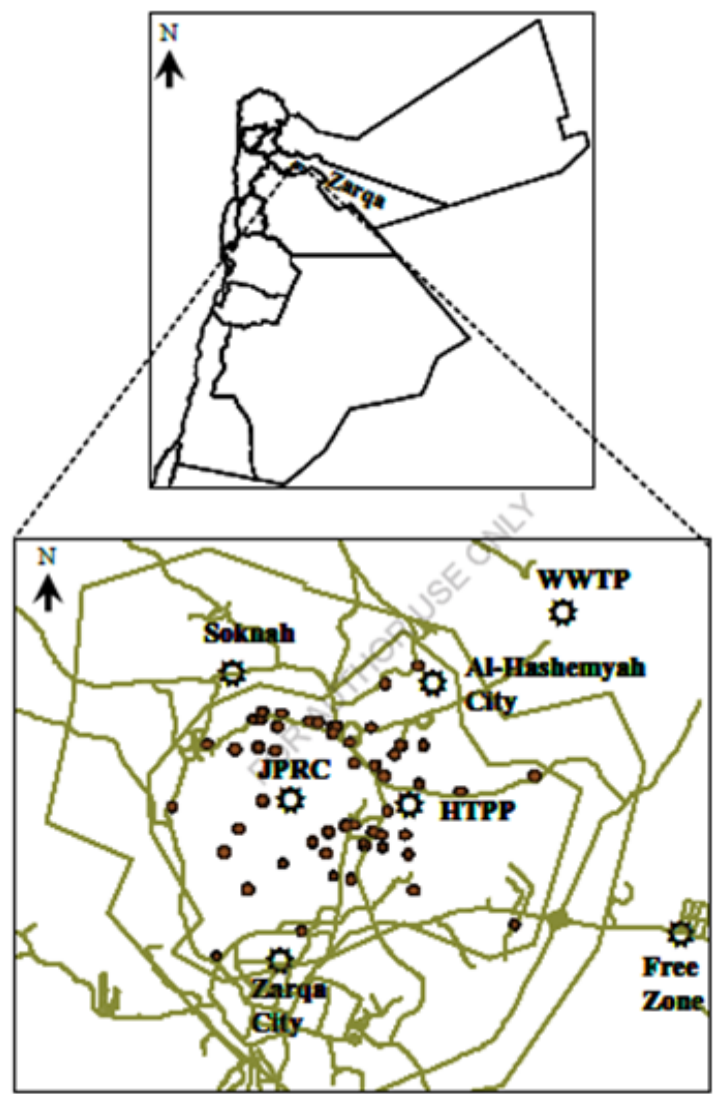

Fig 1. Jordan map shows the Al-Zarqa city this region. The increased industrial development has facilitated the growth of the city's population. The increased rate of population growth and industries has caused serious environmental problems in this region.

\section{Sampling strategy}

About one kilometer was included for acquiring the soil samples from the studied area. Different samples were collected with the help of an auger and were transferred into labeled polyethylene bags. The sample bags were labeled according to the sampling area, date, and weight of the collected samples. The samples were also documented with clear details to avoid any mixing between samples.

\section{Sample processing}

The pre-treatment of samples was performed by cleaning all glassware with tap water, detergent, and distilled water. Then the glassware was soaked in $10 \%$ $\mathrm{HNO}_{3}(\mathrm{v} / \mathrm{v})$ for one night. Finally, all glassware was cleaned and rinsed with deionized water. The collected samples were spread out to separate the extra materials such as grass, stones, mosses, and roots. All materials sized above $2 \mathrm{~cm}$ were separated from the samples using physical procedures. Afterwards, the samples were airdried at room temperature for two weeks by placing them in a clean area. Later, the dried sections were sieved through $2 \mathrm{~mm}$ mesh; the attained sections were then further divided into three labeled polyethylene bags. These samples were stored at $4{ }^{\circ} \mathrm{C}$ in a refrigerator until it was time to perform the chemical analysis.

\section{Chemical analysis}

pH. The $\mathrm{pH}$ of all collected soil samples was measured by making a 1:1 ratio of soil and deionized water mixture $(\mathrm{w} / \mathrm{v})$. A potentiometric approach was used to measure the $\mathrm{pH}$ following the EPA standard analysis method 9045D [20]. The measured $\mathrm{pH}$ values were reported as $\mathrm{pH}\left(\mathrm{H}_{2} \mathrm{O}\right)$ at $25^{\circ} \mathrm{C}$.

Cation exchange capacity (CEC). An excess of sodium acetate solution mixed with soil samples resulted in the exchange of sodium cations with matrix cations. The mixture was then rinsed with isopropyl alcohol. Ammonium acetate solution was later added, which exchanged the adsorbed sodium with ammonium ion. This sample was then embedded in each batch (8 samples). In addition, a blank was embedded within 
every three successive batches. The concentration of the released $\mathrm{Na}^{+}$was determined by atomic emission spectroscopy at $589 \mathrm{~nm}$ wavelength. The results were shown in centimoles of positive charge per kilogram of soil $(\mathrm{cmol}[+] / \mathrm{kg}) ;(\mathrm{cmol} \mathrm{Na}=\{$ (weight of $\mathrm{Na}$ in the sample/ atomic weight of $\mathrm{Na}) \times 100\})$.

Total organic carbon (TOC). A $0.15 \mathrm{~mm}$ sieve was used to sieve soil samples, and about $0.5 \mathrm{~g}$ of soil that passed the sieve was weighed to the nearest of $0.0001 \mathrm{~g}$ and placed in a digestion tube $(250 \mathrm{~mL})$. Then, $15 \mathrm{~mL}$ of the digestion solution ( $0.066 \mathrm{M} \mathrm{K}_{2} \mathrm{Cr}_{2} \mathrm{O}_{7}$ and $9 \mathrm{M} \mathrm{H}_{2} \mathrm{SO}_{4}$ ) was poured into the digestion tube and boiled gently over a hot plate for $45 \mathrm{~min}$. The digested samples were then allowed to cool before adding $50 \mathrm{~mL} \mathrm{H}_{2} \mathrm{O}, 5 \mathrm{~mL} 85 \% \mathrm{H}_{3} \mathrm{PO}_{4}$, and four drops of the indicator (o-Phenanthroline). Finally, the solution was titrated against ferrous ammonium sulfate with the endpoint color change from green to reddishbrown. The quality of the analysis was monitored by triplicate analysis of a known sample, and then it was embedded with each batch (10 samples). In addition, two unheated blanks and two heated blanks were also analyzed with each batch. Before titration, ferrous ammonium sulfate solution was standardized against $\mathrm{K}_{2} \mathrm{Cr}_{2} \mathrm{O}_{7}$. The TOC of the samples was reported as a percentage of TOC.

Metals. About $0.5 \mathrm{~g}$ of each air-dried and sieved samples were taken and placed in a Teflon beaker. Around $15 \mathrm{~mL}$ of $\mathrm{HNO}_{3}, 4 \mathrm{~mL}$ of $\mathrm{HF}$, and $4 \mathrm{~mL}$ of $\mathrm{HClO}_{4}$ were added to the sample filled beakers, and the attained mixtures were then boiled in a sand bath at $170 \pm 20^{\circ} \mathrm{C}$. The boiling was done in closed beakers until the samples were completely dissolved. Then the covers were removed to allow the solution to evaporate and become dry. Afterwards, $5 \mathrm{~mL}$ of $\mathrm{HNO}_{3}$ was dropped into the samples and evaporated until $2 \mathrm{~mL}$ was left. Then the mixture was diluted with deionized water. The obtained mixtures were kept in polyethylene bottles. All samples were again labeled and documented in sample preparation sheets.

Flame atomic absorption spectrometry analysis was performed for all obtained samples, certified reference materials, reagent blanks, and method blanks. An air-acetylene flame was utilized in the spectrometer to attain the details of present metals. The stock solution of $1000 \mathrm{ppm}$ was obtained, and different successive dilutions were prepared to attain the calibration graphs. The graphs were analyzed to identify the linear relationship. Table 1 presents all-instrumental parameters used in this experiment.

\section{Method validation}

The accurate analysis of metal contamination requires comparison with blank measurements. The contamination of metals was detected by measuring the sample to blank ratios. Blank samples or acid samples were prepared and treated like samples. The effects of used acids and reagents were calculated. The sample to blank ratios of all metals except $\mathrm{Cd}$ were estimated to be larger than 10, while the sample to blank ratio of $\mathrm{Cd}$ was measured around 9. These findings suggest that blank subtraction has no significant impact on the observed concentrations of metals. The limits of detection of the measured metals were also calculated, and the results indicate that measured elements were higher than the LOD, Table 2.

The limits of detection (LOD) of the identified metals in the samples were measured as the concentration

Table 1. The instrumental parameters used in this study

\begin{tabular}{lccccc}
\hline Element & $\lambda(\mathrm{nm})$ & $\begin{array}{c}\text { Air flow } \\
(\mathrm{L} / \mathrm{min})\end{array}$ & $\begin{array}{c}\text { Acetylene flow } \\
(\mathrm{L} / \mathrm{min})\end{array}$ & $\begin{array}{c}\text { Slit width } \\
(\mathrm{nm})\end{array}$ & $\begin{array}{c}\text { Lamp current } \\
(\mathrm{mA})\end{array}$ \\
\hline $\mathrm{Pb}$ & 217.0 & 3.5 & 1.5 & 1.0 & 10.0 \\
$\mathrm{Cr}$ & 357.9 & 4.0 & 2.5 & 0.2 & 7.0 \\
$\mathrm{Cd}$ & 228.8 & 3.5 & 1.5 & 0.5 & 4.0 \\
$\mathrm{Zn}$ & 213.9 & 3.5 & 1.5 & 1.0 & 5.0 \\
$\mathrm{Cu}$ & 324.8 & 3.5 & 1.5 & 0.5 & 4.0 \\
$\mathrm{Ni}$ & 232.0 & 3.5 & 1.5 & 0.2 & 4.0 \\
$\mathrm{Mn}$ & 279.5 & 3.5 & 1.5 & 0.2 & 5.0 \\
$\mathrm{Fe}$ & 386.0 & 3.5 & 1.5 & 0.2 & 5.0 \\
\hline
\end{tabular}


Table 2. Sample to blank ratio and detection limits of elements

\begin{tabular}{lcccc}
\hline Elements & $\begin{array}{c}\text { Average concentration } \\
(\mathrm{mg} / \mathrm{L})\end{array}$ & $\begin{array}{c}\text { Average blank } \\
\text { concentration }(\mathrm{mg} / \mathrm{L})\end{array}$ & $\begin{array}{c}\text { Sample to blank } \\
\text { ratio }\end{array}$ & LOD (mg/L) \\
\hline $\mathrm{Cu}$ & 1.113 & 0.015 & 74 & 0.013 \\
$\mathrm{Ni}$ & 4.140 & 0.119 & 35 & 0.053 \\
$\mathrm{Zn}$ & 2.582 & 0.180 & 20 & 0.004 \\
$\mathrm{Mn}$ & 3.437 & 0.029 & 119 & 0.011 \\
$\mathrm{~Pb}$ & 2.501 & 0.040 & 63 & 0.031 \\
$\mathrm{Cd}$ & 0.037 & 0.0048 & 9 & 0.008 \\
$\mathrm{Cr}$ & 0.883 & 0.043 & 21 & 0.040 \\
$\mathrm{Fe}$ & 396 & 0.27 & 1467 & 1.25 \\
\hline
\end{tabular}

${ }^{\mathrm{a}}$ : Blank levels were below the detection limits. Therefore, half of the detection limit was used to calculate the sample to blank ratio

that produces three times the $\mathrm{SD}$ at a particular wavelength. The LOD was calculated for each sample with the help of a blank sample. The calculated values were much higher than the Limits of detection. A periodic examination of Standard Reference Materials (SRM) was performed to assure the accuracy of the results. The SRM was collected from the National Institute of Standards and Technology. The results of the SRM were found to be fairly close to the certified values. Table 3 represents the list of SRMs used in this study, and Table 4 shows the accuracy and precision based on three standard reference materials for FAAS analysis.

\section{Method of heavy metal pollution assessment}

This study utilized extensive field research, and it is derivative in nature. The collected soil samples were examined for the presence of metals. Geostatistical methods were used for the mapping of metal concentrations. The correlation analysis was used for principal components analysis of the collected soil samples.

\section{- RESULTS AND DISCUSSION \\ Chemical Characteristics of Soil}

The descriptive analyses of the chemical properties of the topsoil samples collected from Al-Zarqa city are presented in Table 5. The studied chemical properties include $\mathrm{pH}$, total organic carbon (\%TOC), and cation exchange capacity (CEC). A conventional $\mathrm{pH}$ scale 1-14 was used to measure the $\mathrm{pH}$ of soil at $25^{\circ} \mathrm{C}$. The $\%$ TOC indicates the total organic carbon per gram of soil. CEC indicates the centimoles of the sodium cation per kilogram

Table 3. Standard reference materials used in the study

\begin{tabular}{ll}
\hline SRM code & Material \\
\hline SRM-1646aS & Estuarine sediments \\
SRM-1633b & Trace elements in coal fly ash \\
SRM-2702 & Inorganics in marine sediments \\
\hline
\end{tabular}

Table 4. Accuracy and precision based on three standard reference materials for FAAS analysis

\begin{tabular}{lcccccc}
\hline \multicolumn{5}{c}{ Accuracy and precision based on three standard reference materials for FAAS analyses } \\
\hline \multirow{2}{*}{ Elements } & \multicolumn{2}{c}{ SRM-1646a } & \multicolumn{2}{c}{ SRM-1633b } & \multicolumn{2}{c}{ SRM-2702 } \\
\cline { 2 - 7 } & Found \pm SD & Certified \pm SD & Found \pm SD & Certified \pm SD & Found \pm SD & Certified \pm SD \\
\hline $\mathrm{Cu}$ & $10.53 \pm 2.01$ & $10.01 \pm 0.34$ & $107.0 \pm 3.34$ & $112.8 \pm 2.6$ & $102.2 \pm 3.77$ & \\
$\mathrm{Cr}$ & $45.2 \pm 3.5$ & $40.9 \pm 1.9$ & $352 \pm 54$ & $352 \pm 22$ & 202 & $198.2 \pm 4.7$ \\
$\mathrm{Ni}$ & $24.4 \pm 2.3$ & 23 & $146.1 \pm 12.9$ & $102.6 \pm 1.8$ & $78.3 \pm 4.8$ & $75.4 \pm 1.5$ \\
$\mathrm{~Pb}$ & $12.9 \pm 4.6$ & $11.7 \pm 1.2$ & $73.7 \pm 9.4$ & $68.2 \pm 1.1$ & $135.6 \pm 16.7$ & $132.8 \pm 1.1$ \\
$\mathrm{Cd}$ & $0.18 \pm 0.18$ & $0.15 \pm 0.01$ & $2.43 \pm 0.29$ & $0.784 \pm 0.01$ & $0.99 \pm 0.22$ & $0.82 \pm 0.01$ \\
$\mathrm{Zn}$ & $55.0 \pm 2.9$ & $48.9 \pm 1.6$ & $214.0 \pm 2.7$ & 210 & $479.2 \pm 1.4$ & $485.3 \pm 4.2$ \\
$\mathrm{Mn}$ & $236.0 \pm 10.9$ & $234.5 \pm 2.8$ & $133.9 \pm 1.5$ & $131.8 \pm 1.7$ & $1685 \pm 64$ & $1757 \pm 58$ \\
${ }^{\circ} \mathrm{Fe}$ & $2.15 \pm 0.19$ & $2.00 \pm 0.04$ & $7.70 \pm 0.53$ & $7.78 \pm 0.23$ & $7.81 \pm 0.28$ & $7.91 \pm 0.24$ \\
\hline
\end{tabular}

Note: all concentrations are in $\mu \mathrm{g} / \mathrm{g}$ except for $\mathrm{Fe}$ in $(\mathrm{w} / \mathrm{w})$ percent 
of soil ( $\left.\mathrm{cmol}\left[\mathrm{Na}^{+}\right] / \mathrm{kg}\right)$, as presented in Table 5 .

The results indicate that the $\mathrm{pH}$ of all studied samples was between 7.0-8.2, with an average of 7.7. These findings suggest that the soil was neutral to slightly alkaline in nature. $\mathrm{pH}$ is an important chemical property that plays a decisive role in the determination of the behavior of different chemical components of soil samples such as metals. Acidic $\mathrm{pH}$ is more favorable for the mobility of metal ions, while alkaline $\mathrm{pH}$ usually limits the bioavailability of metal ions [6].

The \%TOC values ranged between $0.2-3.6 \%$, while the average of \%TOC for all soil samples was $0.8 \%$. These findings revealed that the distribution patterns of the organic matter in the studied area were irregular. This indicates the variable distributions of the vegetation in the studied region. Abderahman and Abu-Rukah [12] suggested that the extent of organic matter significantly affects the absorption of the heavy metals in soil due to the cation exchange characteristic of organic matter. Therefore, the varied distribution of organic matter also resulted in the varied distribution of heavy-metals throughout the investigated area.

The CEC ranged from 14.46 to $42.9 \mathrm{cmol}\left[\mathrm{Na}^{+}\right] / \mathrm{kg}$ with an average of $28.5 \mathrm{cmol}\left[\mathrm{Na}^{+}\right] / \mathrm{kg}$. It is also evident that the $\mathrm{pH}$ and amount of organic matter have a direct effect on CEC values of soil, and an increase in these values can also increase the CEC values [17].

\section{Measured Concentrations of Metals}

The concentrations of seven metals, $\mathrm{Cd}, \mathrm{Cr}, \mathrm{Cu}, \mathrm{Ni}$, $\mathrm{Mn}, \mathrm{Zn}$, and $\mathrm{Pb}$, were measured in $\mathrm{mg} / \mathrm{kg}$ of the dry weight. The concentration of Fe was measured in w/w or mass to mass ratio of the dry soil. The results revealed that the measured concentrations of all metals were significantly higher than their detection limits. The values of the metals concentrations, their mean, standard deviations (SD), minimum and maximum concentration are presented in Table 6. It is evident that the concentrations of the metals in topsoil are log-normally distributed rather than normally distributed.

There are several factors that can influence the concentration of metals in soil. The important factors which can alter the concentration of heavy metals in soils include $\mathrm{pH}$, the ion-exchange capacity of the organic matter, wind directions, nature, and composition of the soil [21]. The distribution and mobility of metal ions are also varied according to the mentioned soil properties. The findings of the current study indicate that there was a lack of correlation between the $\mathrm{pH}, \mathrm{CEC}$, and \% TOC of the soil samples and the concentrations of the heavy metals. The results of this study show strong agreement with Khashman and Shawabkeh [19].

\section{Comparison with the Literature}

The studied literature and the findings of the present study were matched to analyze the extent of the soil contamination by the studied metals. This comparison increased the understanding of the extent of soil pollution by metals in the investigated area. The metals that include $\mathrm{Pb}, \mathrm{Cd}, \mathrm{Cr}, \mathrm{Zn}, \mathrm{Al}, \mathrm{Fe}$, and $\mathrm{Mn}$, are mostly discussed in the literature as heavy metal pollutants

Table 5. Chemical characteristics of soil

\begin{tabular}{lccccc}
\hline & Average & SD & Median & Min & Max \\
\hline \% TOC & 0.8 & 0.6 & 0.6 & 0.2 & 3.6 \\
CEC & 28.5 & 6.6 & 27.8 & 14.6 & 42.9 \\
\hline
\end{tabular}

Table 6. The concentration of metals in the studied area

\begin{tabular}{ccrrrrrr}
\hline Metals & Unit & Mean & SD & Median & G. Mean & Min & Max \\
\hline $\mathrm{Cd}$ & $\mathrm{mg} / \mathrm{kg}$ & 6.6 & 5.2 & 4.8 & 5.5 & 2.3 & 27.1 \\
$\mathrm{Cr}$ & $\mathrm{mg} / \mathrm{kg}$ & 88.2 & 29.4 & 84.0 & 83.8 & 41.6 & 183.1 \\
$\mathrm{Cu}$ & $\mathrm{mg} / \mathrm{kg}$ & 21.7 & 8.8 & 19.10 & 20.8 & 9.2 & 57.1 \\
$\mathrm{Mn}$ & $\mathrm{mg} / \mathrm{kg}$ & 492.2 & 164.3 & 502 & 459.0 & 79.2 & 932.4 \\
$\mathrm{Ni}$ & $\mathrm{mg} / \mathrm{kg}$ & 113.1 & 128.5 & 62.2 & 81.7 & 41.9 & 600.5 \\
$\mathrm{~Pb}$ & $\mathrm{mg} / \mathrm{kg}$ & 58.9 & 30.6 & 64.0 & 47.8 & 5.7 & 166.7 \\
$\mathrm{Zn}$ & $\mathrm{mg} / \mathrm{kg}$ & 122.0 & 71.2 & 109.9 & 105.9 & 27.8 & 356.2 \\
$\mathrm{Fe}$ & $\%(\mathrm{w} / \mathrm{w})$ & 1.8 & 1.0 & 1.6 & 1.6 & 0.2 & 4.8 \\
\hline
\end{tabular}


in soil $[17,21]$. The literature also indicated that these metals are the more frequently occurring metal pollutants in urban soil [22-23]. The comparison of the metal concentrations in soil in the present study and the reported metal concentrations in literature are presented in Table 7.

The result indicates that $\mathrm{Cd}$ concentrations in the studied areas ranged from 2.3 to $27.1 \mathrm{mg} / \mathrm{kg}$, with a mean concentration of $6.6(\mathrm{mg} / \mathrm{kg})$. This suggests that the mean concentration of $\mathrm{Cd}$ in the current study is around 30 times higher than that was found in the proximity of an oil refinery in Spain. This concentration is also higher than what had been found in the Ankara region [18,23]. The obtained Cd concentration in the current research validates the previously measured concentrations of $\mathrm{Cd}$ in this region which was $7.0 \mathrm{mg} / \mathrm{kg}$ [25].

The $\mathrm{Cr}$ concentration ranged from 41.6 to $183.1 \mathrm{mg} / \mathrm{kg}$, with a mean concentration of $88.2 \mathrm{mg} / \mathrm{kg}$. Comparison with previous studies shows that this measured concentration is almost 5 times higher than the $\mathrm{Cr}$ concentration measured in the proximity of an oil refinery in Spain and 4 times higher than the calculated values for the nearby area of JPRC [26]. The comparison also revealed that the measured values of $\mathrm{Cr}$ concentration in this study were in close agreement with the results of Banat et al. [18] and significantly lower than the $\mathrm{Cr}$ concentration in the Ankara region as measured by Yay et al. [23].

The calculated values of $\mathrm{Cu}$ concentration in the current study ranged from 9.2 to $57.1 \mathrm{mg} / \mathrm{kg}$, with a mean concentration of $21.7 \mathrm{mg} / \mathrm{kg}$. The comparison analysis revealed that the $\mathrm{Cu}$ values found in this study are much lower than the previously stated concentration by Momani et al. [26]. These values are also lower than the reported $\mathrm{Cu}$ concentration for the Ankara region [23]. However, the means of concentrations of these results are still higher than the values measured by AlKhashman [16].

The Ni concentrations in this study ranged from 41.9 to $600.5 \mathrm{mg} / \mathrm{kg}$, with a mean concentration of $113.1 \mathrm{mg} / \mathrm{kg}$. The comparison analyses revealed that the mean concentration of $\mathrm{Ni}$ in the current study is 40 times greater than the previously measured $\mathrm{Ni}$ concentration by Al-Khashman [16], but lower than $121.5 \mathrm{mg} / \mathrm{kg}$, which is the value reported earlier in JPRC by Al-Shatnawi [25].

$\mathrm{The} \mathrm{Pb}$ concentrations in the current study ranged from 5.7 to $166.7 \mathrm{mg} / \mathrm{kg}$, with a mean concentration of $58.9 \mathrm{mg} / \mathrm{kg}$. This value is slightly lower than the value calculated by Banat et al. [18]. However, the average concentration of $\mathrm{Pb}$ is significantly greater than the formerly reported values in other literature [16,24]. The values reported by Yay et al. [23] for the Ankara region were 3 times greater than the results of the present research.

The measured concentrations of $\mathrm{Zn}$ in this study ranged from 27.8 to $356.23 \mathrm{mg} / \mathrm{kg}$ with a mean value of $122.0 \mathrm{mg} / \mathrm{kg}$. This mean value is in close agreement with the values reported by Al-Shatnawi [25], which was $127.5 \mathrm{mg} / \mathrm{kg}$. However, when compared to the results obtained by Banat et al. [18] and Yay et al. [23] the measured concentrations of $\mathrm{Zn}$ in the current study are lower.

Table 7. Comparison of metal concentrations with literature

\begin{tabular}{lcccccr}
\hline Metals & Results of this study & JPRC $^{\mathrm{a}}$ & Cement $^{\mathrm{b}}$ & Ind. Estate & Oil refinery & Ankara $^{\mathrm{e}}$ \\
\hline $\mathrm{Cd}$ & 6.6 & 1.2 & 5.0 & & 0.2 & 2.2 \\
$\mathrm{Cr}$ & 88.2 & 23.0 & 83.9 & & 16.5 & 284.0 \\
$\mathrm{Cu}$ & 21.7 & 28.0 & & 11.3 & & 90.0 \\
$\mathrm{Mn}$ & 492.2 & & & & 268.9 & 1100.0 \\
$\mathrm{Ni}$ & 113.1 & & & 4.2 & & 81.0 \\
$\mathrm{~Pb}$ & 58.9 & 21.0 & 62.2 & 11.2 & 37.8 & 189.0 \\
$\mathrm{Zn}$ & 122.0 & 104.0 & 146.9 & 13.1 & & 181.0 \\
$\mathrm{Fe}$ & 18200 & 3755 & & 43 & & 858000 \\
\hline
\end{tabular}

${ }^{\mathrm{a}}[26] ;{ }^{\mathrm{b}}[18] ;{ }^{\mathrm{c}}[16] ;{ }^{\mathrm{d}}[23-24] ;{ }^{\mathrm{e}}[22]$ 


\section{Probability Distribution}

The Gaussian Distribution is a well-recognized technique for factor analysis and geostatistical analysis [27]. These techniques help in attaining the approximately normal data while the non-normality is apparent in the collected data. The shape and symmetry of distribution are measured by analyzing the Kurtosis and skewness of the distribution. The normal distribution is considered to be symmetric and has a zero value for its skewness. In this study, the obtained values of metals and values of soil properties were not normally distributed. Therefore, these values were normalized via logarithmic transformation to normalize the positively skewed distribution of heavy metal concentrations [28]. The Kolmogorov-Smirnov (KS) test for normality was performed. The findings of this test are presented in Table 8.

The raw data showed positively skewed values for the obtained concentrations of all metals except for Mn. This result suggests that there are various processes such as mineralization and other pollutants that affect the concentration of these metals. The value of the K-S test for normality of $\mathrm{Cr}, \mathrm{Cu}, \mathrm{Fe}, \mathrm{Mn}$, and $\mathrm{Pb}(\mathrm{p}>0.05)$ indicates that their concentrations can be normalized. However, the values of $\mathrm{Pb}$ and $\mathrm{Ni}$ did not pass the K-S test for normality. The log-normal transformation was used to minimize data skewness. Fig. 2 illustrates the comparison of the skewed distribution of data before and after the log-transformation of the data.

\section{Sources Identification}

A factor analysis (FA) was conducted for the identification of the minimum number of common factors that have the potential to impact the variance of heavy metal concentration in soil. There is no specific rule for the identification of factors and deciding how many factors should be included in FA. However, the common rule is to either keep factors with eigenvalues higher than 1.0 or keep all interpretable factors. The results of probability distribution and log transferred data were then analyzed under factor analysis, and then a varimax (orthogonal) rotation was also applied.

The factor analysis of the metals data set revealed that only the first three factors have eigenvalues higher than 1 . The scree-test results also indicated that the first three factors are meaningful for source identification. The findings suggest that the first factor (FA1) explains $45.8 \%$ of the total variance. It was highly loaded with $\mathrm{Zn}(0.94)$ and $\mathrm{Pb}(0.94)$ and moderately loaded by $\mathrm{Cu}(0.71)$ and $\mathrm{Cr}$ (0.64). Since $\mathrm{Pb}, \mathrm{Cu}$, and $\mathrm{Zn}$ are identified as traffic markers by several authors, FA1 was assigned as a trafficking factor. The results showed that the second factor (FA2) explains $20.3 \%$ of the total variance. It was highly loaded with $\mathrm{Ni}(0.90)$ and moderately loaded by $\mathrm{Fe}$ (0.73). Moreover, $\mathrm{Cr}$ was distributed between FA1 and FA2. Ni has been identified as an important marker of oil combustion; therefore, this factor was assigned to oil refinery emission.

The third factor (FA3) (FA3) was highly loaded with $\mathrm{Cd}(0.85)$ and moderately loaded with $\mathrm{Mn}$ and Fe. Mn had high loadings on the first and third factors, 0.59 and 0.64 , respectively, but was even higher on the third factor. Moreover, $\mathrm{Fe}$ (0.46) had comparatively significant loading in FA3. Fe and $\mathrm{Mn}$ are well recognized to be linked with industrial processes. The presence of $\mathrm{Cd}$, along

Table 8. Shape statistics and results of the Kolmogorov-Smirnov (K-S) test for the raw and log-normally transformed data

\begin{tabular}{lcccccc}
\hline \multirow{2}{*}{ Metal } & \multicolumn{3}{c}{ Raw data } & \multicolumn{4}{c}{ Log-normal transformed data } \\
\cline { 2 - 7 } & Skewness & Kurtosis & K-S & Skewness & Kurtosis & K-S p \\
\hline $\mathrm{Cd}$ & 2.7 & 7.5 & 0.00 & 1.2 & 1.6 & 0.14 \\
$\mathrm{Cr}$ & 1.2 & 2.1 & 0.12 & 0.05 & 0.3 & 0.69 \\
$\mathrm{Cu}$ & 1.9 & 5.21 & 0.12 & 0.42 & 0.8 & 0.74 \\
$\mathrm{Fe}$ & 0.8 & 0.4 & 0.37 & -0.15 & -0.5 & 0.97 \\
$\mathrm{Mn}$ & 0.14 & 0.9 & 0.97 & -1.8 & 5.45 & 0.24 \\
$\mathrm{Ni}$ & 2.7 & 6.5 & 0.00 & 1.6 & 1.45 & 0.00 \\
$\mathrm{~Pb}$ & 0.37 & 1.6 & 0.39 & -1.3 & 0.8 & 0.00 \\
$\mathrm{Zn}$ & 1.8 & 3.4 & 0.04 & -0.02 & 0.5 & 0.79 \\
\hline
\end{tabular}



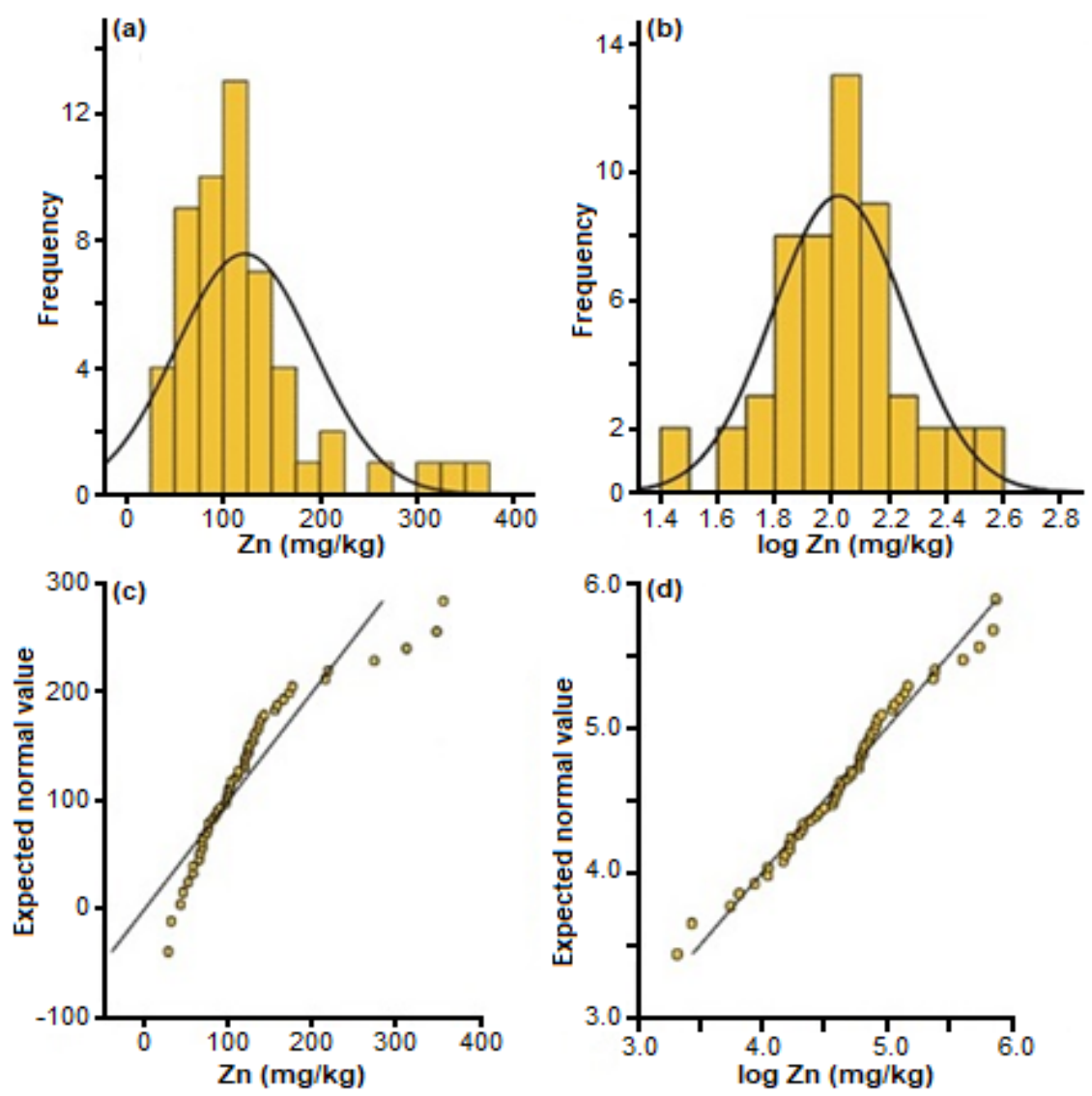

Fig 2. (a) Histogram of $\mathrm{Zn}$ concentrations in soil samples showing a skewed distribution, (b) Histogram of the logtransformed $\mathrm{Zn}$ concentrations showing normal distribution. (c) Q-Q plot of $\mathrm{Zn}$ concentrations showing a deviation from linearity, (d) Q-Q plot of the log-transformed Zn concentrations

Table 9. Correlation matrix of metals

\begin{tabular}{lccccccc}
\hline & $\mathrm{Cd}$ & $\mathrm{Cr}$ & $\mathrm{Cu}$ & $\mathrm{Fe}$ & $\mathrm{Mn}$ & $\mathrm{Ni}$ & $\mathrm{Pb}$ \\
\hline $\mathrm{Cr}$ & $\mathbf{0 . 0 5}$ & & & & & & \\
$\mathrm{Cu}$ & 0.05 & 0.53 & & & & & \\
$\mathrm{Fe}$ & -0.33 & 0.61 & 0.29 & & & & \\
$\mathrm{Mn}$ & -0.24 & 0.47 & 0.35 & 0.43 & & & \\
$\mathrm{Ni}$ & -0.13 & 0.42 & 0.20 & 0.52 & 0.11 & & \\
$\mathrm{~Pb}$ & 0.20 & 0.57 & 0.57 & 0.25 & 0.45 & 0.20 & \\
$\mathrm{Zn}$ & 0.20 & 0.57 & 0.57 & 0.25 & 0.45 & 0.20 & 1.00 \\
\hline
\end{tabular}

Table 10. Factor loadings from factor analysis after rotation for the maximum variance

\begin{tabular}{lcccc}
\hline Elements & FA1 & FA2 & FA3 & Communalities \\
\hline $\mathbf{Z n}$ & $\mathbf{0 . 9 4}$ & & & 0.90 \\
$\mathbf{P b}$ & $\mathbf{0 . 9 4}$ & & & 0.90 \\
$\mathbf{C u}$ & $\mathbf{0 . 7 1}$ & & & 0.54 \\
$\mathbf{C r}$ & $\mathbf{0 . 6 4}$ & $\mathbf{0 . 5 7}$ & & 0.74 \\
$\mathbf{N i}$ & & $\mathbf{0 . 9 0}$ & & 0.82 \\
$\mathbf{F e}$ & & $\mathbf{0 . 7 3}$ & 0.46 & 0.79 \\
$\mathrm{Cd}$ & & $\mathbf{0 . 8 5}$ & 0.80 \\
$\mathrm{Mn}$ & $\mathbf{0 . 5 9}$ & & $\mathbf{0 . 6 4}$ & 0.76 \\
\hline Variance & $45.8 \%$ & $20.3 \%$ & $12.1 \%$ & $78.2 \%$ \\
\hline \multicolumn{2}{l}{ Total Variance Explained, \% } & & & 78.2 \\
\hline
\end{tabular}


with these metals, indicates the occurrence of anthropogenic activities. Zarqa city has an industrial zone with four steel smelters [29]. Therefore, FA3 was assigned to mixed anthropogenic factors. The findings of factor analysis are presented in Table 9 and Table 10.

The outcomes of the factor analysis revealed that the chief sources of metals in topsoil include anthropogenic processes, oil burning, and emission from an oil refinery and steel industries.

\section{The Spatial Distribution Analysis}

The results obtained in this study present significant matching with earlier documented distribution patterns of $\mathrm{Pb}$ and $\mathrm{Zn}$ concentrations in Al-Zarqa city. The geochemical map shows that the distribution of the concentrations of these metals was lower than the maximum allowable limits in other countries, including Germany, UK, Japan, and Canada. It was also identified that the distribution of $\mathrm{Cu}$ was close to $\mathrm{Pb}$ and $\mathrm{Zn}$ concentrations. Factor analysis confirmed these results; the first factor was highly loaded by $\mathrm{Pb}$ and $\mathrm{Zn}$ and moderately loaded by $\mathrm{Cu}$ and $\mathrm{Cr}$. The results indicate that these heavy metals are uniformly distributed in the studied areas, and there were no major hotspots present for these elements as shown in Fig. 3. This homogeneous distribution pattern indicates that the sources for their emission are mobile sources. Therefore, automobile and vehicle emission was a major source for these elements.

The geochemical map showed that the studied area was significantly polluted with $\mathrm{Cd}$ as its measured concentration crossed the max allowable limits in the UK, Germany, Poland, and Australia (2 mg/kg). Moreover, a major hotspot was also identified in the new Al-Zarqa city with a $\mathrm{Cd}$ concentration of around $27.1 \mathrm{mg} / \mathrm{kg}$. The other studied areas were less polluted while the northern outskirts were identified to have the lowest concentration of $\mathrm{Cd}(<5.6 \mathrm{mg} / \mathrm{kg})$. The same area was also identified for $\mathrm{Cu}$ hotspot as shown in Fig. 4. This distribution pattern indicates that there were $\mathrm{Cd}$ and $\mathrm{Cu}$ emitting sources present in the area. The topographic map
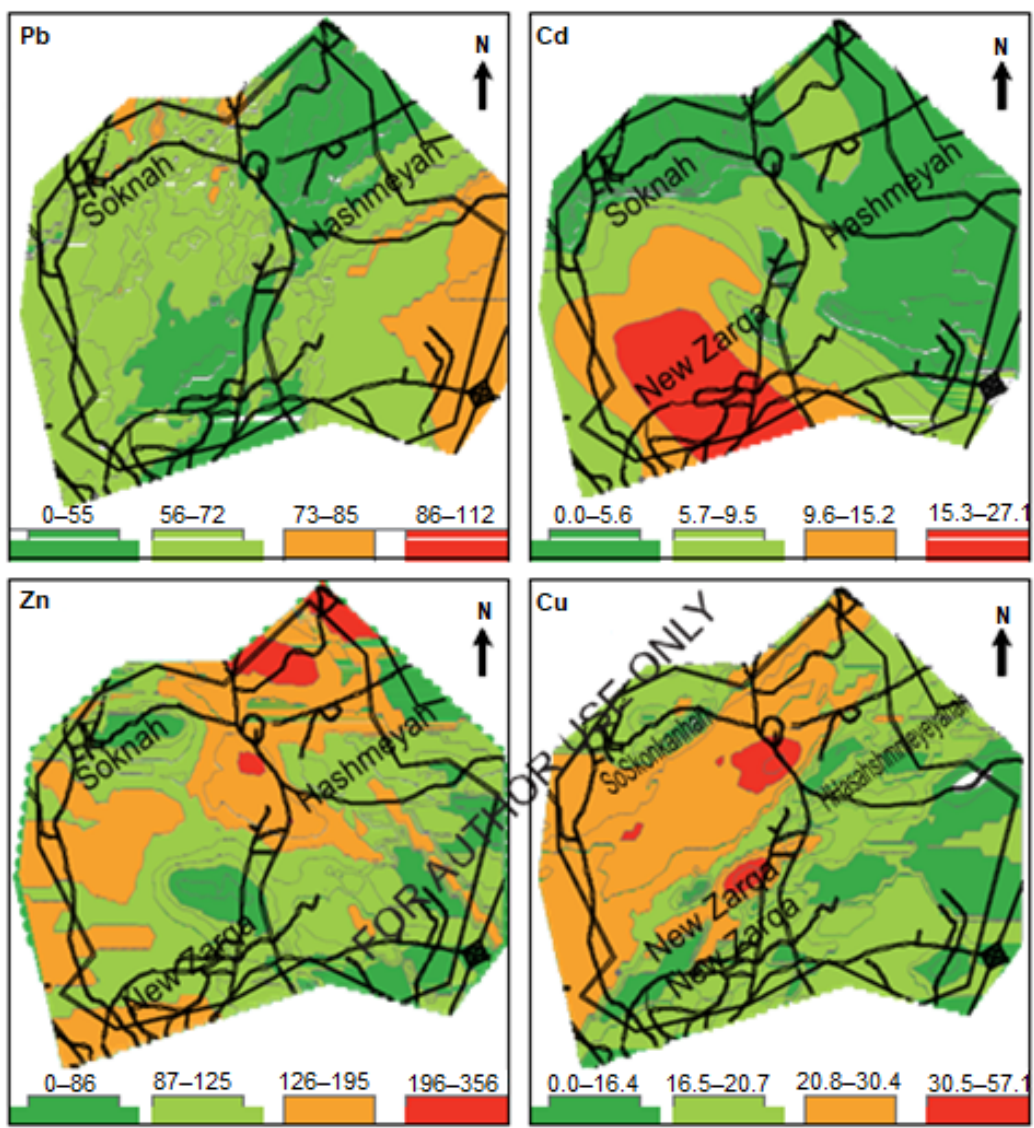

Fig 3. Spatial distribution of metals $(\mathrm{Pb}, \mathrm{Cd}, \mathrm{Zn}, \mathrm{Cu})$ 

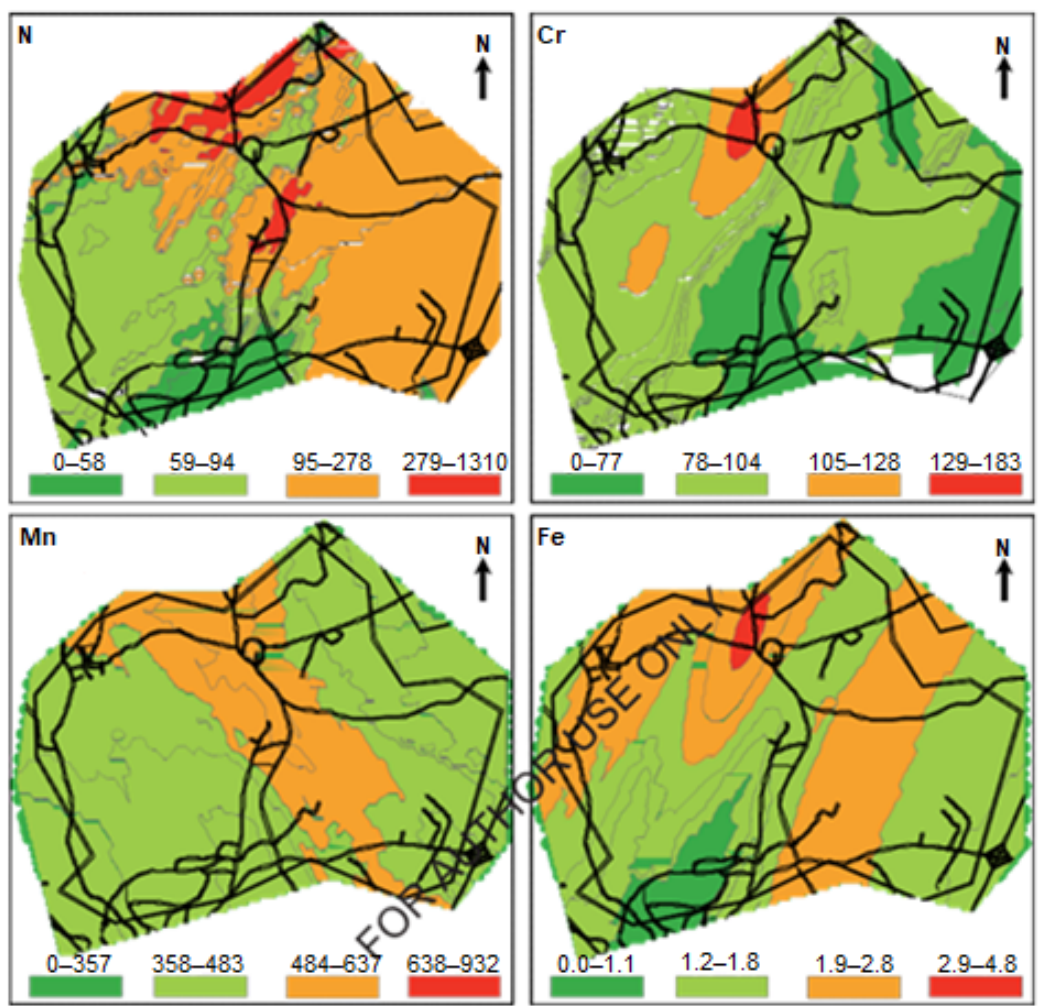

Fig 4. Spatial distribution of metals ( $\mathrm{Mn}, \mathrm{Fe}, \mathrm{Cr}, \mathrm{Ni})$

of this region suggests the presence of several industrial constructions; however, the nature of these industries was not identified.

These findings also revealed that the studied area was considerably polluted with $\mathrm{Ni}$ as its measured concentration was more than the maximum allowable limits in Australia, Poland, Canada, Japan, and Germany. The major hotspots for Ni concentration were seen in the east and north of the JPRC. There was no significant information about the distribution of industrial activities available; therefore, any correlation between the hotspot and their sources was difficult to identify. However, it is believed that the burning of oil was the major source of $\mathrm{Ni}$ concentration.

The findings also revealed that the studied area was significantly polluted with $\mathrm{Cr}$, and its concentration was identified to be higher than the maximum allowable limits in the UK and Canada. However, the south-eastern area had a lower concentration of $\mathrm{Cr}$, while the Northwestern area had a higher concentration. More hotspots were found in JPRC nearby locations. The factor analysis further confirmed that JPRC was the key source for the emission of these metals.

The Geochemical maps of Fe and Mn revealed that the greater concentration of these two elements was clustered and not scattered. The widespread crust contribution of these elements attributes to their significantly higher concentrations. One major hotspot for higher concentrations of these metals was identified in the middle of the northern region of the studied area. The existence of human activities and the steel industry in that region was identified as the primary source of these elements. However, to validate this result, more information about these locations and meteorological data is needed.

\section{- CONCLUSION}

Our results indicate that there is a higher degree of heavy metal pollution in Al-Zarqa city. The average values of the measured concentrations of identified metals were as follows; $\mathrm{Cd}$ (6.6), $\mathrm{Cr}$ (88.2), $\mathrm{Cu}$ (21.7), $\mathrm{Ni}$ (113.1), $\mathrm{Pb}$ (58.9), and $\mathrm{Zn}(122.0) \mathrm{mg} / \mathrm{kg}$. The major 
sources for the contribution of these elements in the studied area include traffic, emission from oil-refineries, and mixed anthropogenic sources. The distribution pattern of these metals and the pollution state in AlZarqa city were assessed by comparing the metal's concentrations with the maximum allowable limits (MAL) in different countries. Results showed that the average concentration of $\mathrm{Cd}$ was higher than the MAL in Australia, Poland, UK, and Germany. While the average concentration of $\mathrm{Cr}$ was higher than the MAL in Canada and the UK. Meanwhile, the average concentration of $\mathrm{Cu}$ was lower than the MAL in Australia, Canada, Poland, Japan, UK, and Germany. In addition, the average concentration of $\mathrm{Ni}$ was higher than the MAL in Australia, Canada, Poland, Japan, UK, and Germany. While the average concentration of $\mathrm{Pb}$ and $\mathrm{Zn}$ was lower than the MAL in Australia, UK, Canada, Poland, Japan, and Germany.

\section{- REFERENCES}

[1] Li, Z., Ma, Z., van der Kuijp, T.J., Yuan, Z., and Huang, L., 2014, A review of soil heavy metal pollution from mines in China: Pollution and health risk assessment, Sci. Total Environ., 468-469, 843853.

[2] El-Hasan, T., and Lataifeh, M., 2013, Field and dual magnetic susceptibility proxies for heavy metal pollution assessment in the urban soil of Al-Karak City, South Jordan, Environ. Earth Sci., 69 (7), 22992310.

[3] Fallahzadeh, R.A., Ghaneian, M.T., Miri, M., and Dashti, M.M., 2017, Spatial analysis and health risk assessment of heavy metals concentration in drinking water resources, Environ. Sci. Pollut. Res., 24 (32), 24790-24802.

[4] Zhang, X.Y., Lin, F.F., Wong, M.T., Feng, X.L., and Wang, K., 2009, Identification of soil heavy metal sources from anthropogenic activities and pollution assessment of Fuyang County, China, Environ. Monit. Assess., 154 (1-4), 439.

[5] Gao, X., and Chen, C.T.A., 2012, Heavy metal pollution status in surface sediments of the coastal Bohai Bay, Water Res., 46 (6), 1901-1911.
[6] Wang, S.L., Xu, X.R., Sun, Y.X., Liu, J.L., and Li, H.B., 2013, Heavy metal pollution in coastal areas of South China: A review, Mar. Pollut. Bull., 76 (1-2), 7-15.

[7] Ipeaiyeda, A.R., and Ayoade, A.R., 2017, Flame atomic absorption spectrometric determination of heavy metals in aqueous solution and surface water preceded by co-precipitation procedure with copper(II) 8hydroxyquinoline, Appl. Water Sci., 7 (8), 4449-4459.

[8] Shan, Y., Tysklind, M., Hao, F., Ouyang, W., Chen, S., and Lin, C., 2013, Identification of sources of heavy metals in agricultural soils using multivariate analysis and GIS, J. Soils Sediments, 13 (4), 720-729.

[9] Gworek, B., Dmuchowski, W., Koda, E., Marecka, M., Baczewska, A.H., Brągoszewska, P., and Osiński, P, 2016, Impact of the municipal solid waste Łubna landfill on environmental pollution by heavy metals, Water, 8 (10), 470.

[10] Naser, H.A., 2013, Assessment and management of heavy metal pollution in the marine environment of the Arabian Gulf: A review, Mar. Pollut. Bull., 72 (1), 6-13.

[11] Yaseen, I.A.B., and Al-Hawari, Z., 2015, Assessment of heavy metal pollution of surface sediments in Wadi Shu'ayb, Jordan, Jordan J. Civ. Eng., 9 (3), 303-313.

[12] Al-Khashman, O.A., 2013, Assessment of heavy metals contamination in deposited street dusts in different urbanized areas in the city of $\mathrm{Ma}$ 'an, Jordan, Environ. Earth Sci., 70 (6), 2603-2612.

[13] Li, F., Huang, J., Zeng, G., Yuan, X., Li, X., Liang, J., Wang, X., Tang, X., and Bai, B., 2013, Spatial risk assessment and sources identification of heavy metals in surface sediments from the Dongting Lake, Middle China, J. Geochem. Explor., 132, 75-83.

[14] Pan, H., Lu, X., and Lei, K., 2017, A comprehensive analysis of heavy metals in urban road dust of Xi'an, China: Contamination, source apportionment and spatial distribution, Sci. Total Environ., 609, 13611369.

[15] Al-Najjar, T., Al-Momani, R., Khalaf, M., Wahsha, M., Sbaihat, M., Khalaf, N., Khandra, K.A., and Magames, H., 2016, Levels of heavy metals in fishes (Cheilinus trilobatus) from the Gulf of Aqaba, Jordan, Nat. Sci., 8 (6), 256-263. 
[16] Abderahman, N., and Abu-Rukah, Y.H., 2006, An assessment study of heavy metal distribution within soil in upper course of Zarqa River basin/Jordan, Environ. Geol., 49 (8), 1116-1124.

[17] Linnik, V.G., Minkina, T.M., Bauer, T.V., Saveliev, A.A., and Mandzhieva, S.S., 2019, Geochemical assessment and spatial analysis of heavy metals pollution around coal-fired power station, Environ. Geochem. Health, 2019, s10653-019-00361-z.

[18] Barbeş, L., Bărbulescu, A., Rădulescu, C., Stihi, C., and Chelarescu, E.D., 2014, Determination of heavy metals in leaves and bark of Populus nigra L. by atomic absorption spectrometry, Rom. Rep. Phys., 66 (3), 877-886.

[19] Soodan, R.K., Pakade, Y.B., Nagpal, A., and Katnoria, J.K., 2014, Analytical techniques for estimation of heavy metals in soil ecosystem: A tabulated review, Talanta, 125, 405-410.

[20] Al-Taani, A.A., Batayneh, A.T., El-Radaideh, N., Ghrefat, H., Zumlot, T., Al-Rawabdeh, A.M., AlMomani, T., and Taani, A., 2015, Spatial distribution and pollution assessment of trace metals in surface sediments of Ziqlab reservoir, Jordan, Environ. Monit. Assess., 187 (2), 32.

[21] Massadeh, A.M., and Al-Massaedh, A.A.T., 2018, Determination of heavy metals in canned fruits and vegetables sold in Jordan market, Environ. Sci. Pollut. Res., 25 (2), 1914-1920.

[22] Guo, G., Wu, F., Xie, F., and Zhang, R., 2012, Spatial distribution and pollution assessment of heavy metals in urban soils from southwest China, J. Environ. Sci., 24 (3), 410-418.

[23] Xie, Y., Chen, T., Lei, M., Yang, J., Guo, Q., Song, B., and Zhou, X.Y., 2011, Spatial distribution of soil heavy metal pollution estimated by different interpolation methods: Accuracy and uncertainty analysis, Chemosphere, 82 (3), 468-476.

[24] Alloway, B.J., 1990, "Soil processes and behaviour of metals" in Heavy Metals in Soil, Eds. Alloway, B.J., Blackie and Son Ltd., London, 7-28.

[25] Li, K., Gu, Y., Li, M., Zhao, L., Ding, J., Lun, Z., and Tian, W., 2018, Spatial analysis, source identification and risk assessment of heavy metals in a coal mining area in Henan, Central China, Int. Biodeterior. Biodegrad., 128, 148-154.

[26] Al-Khashman, O.A., 2004, Heavy metal distribution in dust, street dust and soils from the work place in Karak Industrial Estate, Jordan, Atmos. Environ., 38 (39), 6803-6812.

[27] Jaradat, Q.M., Masadeh, A., Zaitoun, M.A., and Maitah, B.M., 2005, Heavy metal contamination of soil, plant and air of scrapyard of discarded vehicles at Zarqa city, Jordan, Soil Sediment Contam., 14 (5), 449-462.

[28] Lü, J., Jiao, W.B., Qiu, H.Y., Chen, B., Huang, X.X., and Kang, B., 2018, Origin and spatial distribution of heavy metals and carcinogenic risk assessment in mining areas at You'xi County southeast China, Geoderma, 310, 99-106.

[29] Banat, K.M., Howari, F.M., and Al-Hamad, A.A., 2005, Heavy metals in urban soils of central Jordan: Should we worry about their environmental risks?, Environ. Res., 97, 258-273.

[30] Al-Khashman, O.A., and Shawabkeh, R.A., 2006, Metals distribution in soils around the cement factory in southern Jordan, Environ. Pollut., 140 (3), 387-394.

[31] Pourjavid, M.R., Arabieh, M., Sehat, A.A., Rezaee, M., Hosseini, M.H., Yousefi, S.R., and Jamali, M.R., 2014, Flame atomic absorption spectrometric determination of $\mathrm{Pb}(\mathrm{II})$ and $\mathrm{Cd}(\mathrm{II})$ in natural samples after column graphene oxide-based solid phase extraction using 4-Acetamidothiophenol, $J$. Braz. Chem. Soc., 25 (11), 2063-2072.

[32] Al-Omari, A., Farhan, I., Kandakji, T., and Jibril, F., 2019, Zarqa River pollution: Impact on its quality, $J$. Environ. Monit. Assess., 191 (3), 166.

[33] Wedyan, M., Al Harahsheh, A., Muhaidat, R., Bsoul, E., and Qnais, E., 2016, Cd and Fe concentrations of the surface water of a stream in Jordan, Pol. J. Environ. Stud., 25 (6), 2617-2621.

[34] USEPA, 2004, Soil and waste pH, method 9045D. United States Environmental Protection Agency.

[35] Al-Momani, I.F., and Shatnawi, W.M., 2017, Chemical characterization and source determination of trace elements in $\mathrm{PM}_{2.5}$ and $\mathrm{PM}_{10}$ from an urban 
area, Northern Jordan, Int. J. Environ. Monit. Anal., 5 (4), 103-108.

[36] Howari, F.M., Abu-Rukah, Y., and Goodell, P.C., 2004, Heavy metal pollution of soils along North Shuna-Aqaba Highway, Jordan, Int. J. Environ. Pollut., 22 (5), 597-607.

[37] Yay, D.O., Alagha, O., and Tuncel, G., 2008, Multivariate statistics to investigate metal contamination in surface soil, J. Environ. Manage., 86 (4), 581-594.

[38] Nadal, M., Schuhmacher, M., and Domingo, J.L., 2007, Levels of metals, PCBs, PCNs and PAHs in soils of a highly industrialized chemical/petro chemical area: Temporal trend, Chemosphere, 66 (2), 267-276.

[39] Al-Shatnawi, S.Y., 2003, Geochemical study of selected toxic heavy metals associated with oil refinery in Al-Hashimeya area, North Jordan, Thesis, Yarmouk University, Jordan.

[40] Momani, K.A., Jaradat, Q.M., Jbarah, A.Q., Omari, A.A., and Al-Momani, I.F., 2002, Water soluble species and heavy metal contamination of the petroleum refinery area, Jordan, J. Environ. Monit., 4 (6), 990-996.

[41] Zhang, C., 2006, Using multivariate analysis and GIS to identify pollutants and their patterns in urban soils in Galway, Ireland, Environ. Pollut., 142 (3), 501-511.

[42] Ghrefat, H.A., Abu-Rukah, Y., and Rosen, M.A., 2011, Application of geoaccumulation index and enrichment factor for assessing metal contamination in the sediments of Kafrain Dam, Jordan, Environ. Monit. Assess., 178 (1), 95-109.

[43] DOS, 2006, Statistical Yearbook, Department of Statistics, Jordan. 